\title{
Review \\ Plant Breeding and Management Strategies to Minimize the Impact of Water Scarcity and Biotic Stress in Cereal Crops under Mediterranean Conditions
}

\author{
Néstor Pérez-Méndez ${ }^{1}$ (D), Cristina Miguel-Rojas ${ }^{2}$ (D), Jose Antonio Jimenez-Berni ${ }^{3}$ (D), David Gomez-Candon ${ }^{4}$ (D), \\ Alejandro Pérez-de-Luque ${ }^{2}\left(\mathbb{D}\right.$, Elias Fereres ${ }^{5,6}$, Mar Catala-Forner ${ }^{1}$ (D) , Dolors Villegas ${ }^{7, *(D)}$ \\ and Josefina C. Sillero ${ }^{2}$ iD
}

check for

updates

Citation: Pérez-Méndez, N.; MiguelRojas, C.; Jimenez-Berni, J.A.; GomezCandon, D.; Pérez-de-Luque, A.; Fereres, E.; Catala-Forner, M.; Villegas, D.; Sillero, J.C. Plant Breeding and Management Strategies to Minimize the Impact of Water Scarcity and Biotic Stress in Cereal Crops under Mediterranean Conditions. Agronomy 2022, 12, 75. https: / / doi.org/10.3390/ agronomy12010075

Academic Editors: Fernando Martinez-Moreno, Magdalena Ruiz, María B. Picó and María-José Díez

Received: 30 November 2021 Accepted: 24 December 2021 Published: 29 December 2021 Publisher's Note: MDPI stays neutral with regard to jurisdictional claims in published maps and institutional affiliations.

Copyright: (c) 2021 by the authors Licensee MDPI, Basel, Switzerland. This article is an open access article distributed under the terms and conditions of the Creative Commons Attribution (CC BY) license (https:// creativecommons.org/licenses/by/ $4.0 /)$.
1 Sustainable Field Crops Program, Institute of Agrifood Research and Technology (IRTA), Carretera de Balada Km 1, 43870 Amposta, Spain; nestor.perez@irta.cat (N.P.-M.); mar.catala@irta.cat (M.C.-F.)

2 IFAPA Alameda del Obispo, Area of Genomic and Biotechnology, Avenida Menéndez Pidal s/n, 14004 Cordoba, Spain; cristinademiguelrojas@gmail.com (C.M.-R.); alejandro.perez.luque@juntadeandalucia.es (A.P.-d.-L.); josefinac.sillero@juntadeandalucia.es (J.C.S.)

3 Instituto de Agricultura Sostenible (IAS), Consejo Superior de Investigaciones Científicas (CSIC), Alameda del Obispo s/n, 14004 Cordoba, Spain; berni@ias.csic.es

4 Efficient Use of Water in Agriculture Program, Institute of Agrifood Research and Technology (IRTA), Fruitcentre, PCiTAL, Parc Científic i Tecnològic Agroalimentari de Gardeny, 25003 Lleida, Spain; david.gomez@irta.cat

5 Department of Agronomy, University of Cordoba, Alameda del Obispo s/n, 14004 Cordoba, Spain; ag1fecae@uco.es

6 IAS-SCIC, Alameda del Obispo s/n, 14004 Cordoba, Spain

7 Sustainable Field Crops Program, Institute of Agrifood Research and Technology (IRTA), Avinguda Rovira Roure 191, 25198 Lleida, Spain

* Correspondence: dolors.villegas@irta.cat

\begin{abstract}
Wheat and rice are two main staple food crops that may suffer from yield losses due to drought episodes that are increasingly impacted by climate change, in addition to new epidemic outbreaks. Sustainable intensification of production will rely on several strategies, such as efficient use of water and variety improvement. This review updates the latest findings regarding complementary approaches in agronomy, genetics, and phenomics to cope with climate change challenges. The agronomic approach focuses on a case study examining alternative rice water management practices, with their impact on greenhouse gas emissions and biodiversity for ecosystem services. The genetic approach reviews in depth the latest technologies to achieve fungal disease resistance, as well as the use of landraces to increase the genetic diversity of new varieties. The phenomics approach explores recent advances in high-throughput remote sensing technologies useful in detecting both biotic and abiotic stress effects on breeding programs. The complementary nature of all these technologies indicates that only interdisciplinary work will ensure significant steps towards a more sustainable agriculture under future climate change scenarios.
\end{abstract}

Keywords: landraces; wheat and rice crops; rust and Septoria resistance; genetic resistance; remote sensing; drought; stress tolerance; biodiversity; water management

\section{Introduction}

Wheat and rice are among the most important cereals at the global scale [1]. The growing area in the world cultivated with wheat occupied in 2019 almost 215 million hectares, with a production of 765 million tons and average yields of $3543 \mathrm{~kg} / \mathrm{ha}$. Rice occupied 162 million ha in 2019, with a global average yield of $4631 \mathrm{~kg} / \mathrm{ha}$ and a total production of 749 million tons [1]. To meet the demands of the growing population, farming systems will need a reconfiguration for a sustainable intensification. To this end, FAO has 
proposed five main strategies, two of them being improvement of crops and varieties and efficient water management [2], which are both the focus of this review.

The most critical factor limiting rainfed cereal yields in the Mediterranean area is drought stress, understood as the negative impact that a water deficit causes on grain yield [3]. Drought is particularly relevant in durum wheat, which represents around $6 \%$ of total wheat cultivation but with an important economic and cultural relevance in Mediterranean countries, where it represents a staple crop [4]. Durum wheat is usually grown under rainfed conditions in environments in which terminal drought and heat are the most frequent stresses constraining grain yield [5]. Semi-arid zones cover up to $18 \%$ of the total land surface of the world and, among other constraints, and they endure reduced water input, erratic rainfall, land degradation, and limited access to agricultural technologies. In this context, changing varieties provides a relatively simple means to enhance the cropping systems, and plant breeding is a very promising activity to improve yields [6].

On the other extreme of water availability, rice is grown under flooded conditions. Rice crops in Mediterranean systems occupy specific small areas, usually near river estuaries, where flatlands and sufficient irrigation water are available. Due to most of these environments being next to the sea, salinity problems are common, and irrigation management plays a key role in preventing soil salinization [7]. Water saving in rice systems, therefore, is not a trivial endeavor, as it implies risks for rice production and soil health. Rice agroecosystems have not only a great socioeconomic importance at the local and regional scales, but they are also considered as artificial wetlands of high environmental richness. For example, rice fields in the Ebro Delta (Spain) represent a unique wetland agroecosystem characterized by a great natural heritage in terms of biodiversity, which granted its inclusion in the EU wide Natura 2000 ecological network (Habitat directive, 94/43 EEC) and the Ramsar Convention. Therefore, to increase agricultural sustainability, innovative water management strategies are needed to reduce potential conflicts among crop production, climate change mitigation, and biodiversity conservation.

Climate change scenarios for the Mediterranean Basin forecast a pronounced decline in precipitation, with increased temperatures, higher evaporative demand, and more frequent occurrence of extreme events. Some predictions estimate rainfall decreases up to $30 \%$ for Mediterranean environments [8], making rainfed agriculture more uncertain and reducing the availability of irrigation water in the future. The enhanced warming will modify the crop developmental patterns by altering flowering dates and growth cycles. The hastening of crop development in cereals in Mediterranean climates will impact yields negatively - in particular, in winter cereals by shortening their life cycle [9]. There is also evidence that climate change is altering the incidence and distribution of pests, diseases [10], and weeds, which is also exacerbated by global trade and the exchange of plant material. If rainfall patterns shift to increased rainfall events during spring, as predicted in some models [11], the risks posed by leaf fungal diseases will also increase under future climate.

Future changes in the environment will increase the uncertainty of interactions between plants and pathogens. Alterations of $\mathrm{CO}_{2}$ concentration, temperature, and water regimes will likely influence, either positively or negatively, the development of crop diseases [12]. On the plant side, pathways leading to resistance or susceptibility can be disrupted, whereas on the pathogen side, virulence, and life cycle (reproduction and survival) could be highly affected. However, every disease and plant-pathogen interaction may respond differently to these changes, which, linked to the multidimensional aspects of such interplay, makes this kind of research an urgent need.

To face the challenges of climate change, two types of strategies have been proposed: mitigation and adaptation. Mitigation strategies in agriculture include carbon sequestration in the soil but also reducing GHG emissions to the atmosphere [6]. It has been shown that certain water management strategies in rice may reduce GHG, but they may also have important side effects on rice production and biodiversity, as discussed in Section 2 of this review. The adaptation strategy will be illustrated by describing the breeding efforts in 
Section 3. Both strategies may be supported and enhanced by a phenomics approach using remote sensing technologies, which is outlined in Section 4. Figure 1 shows a schematic view of the aspects reviewed in this work.

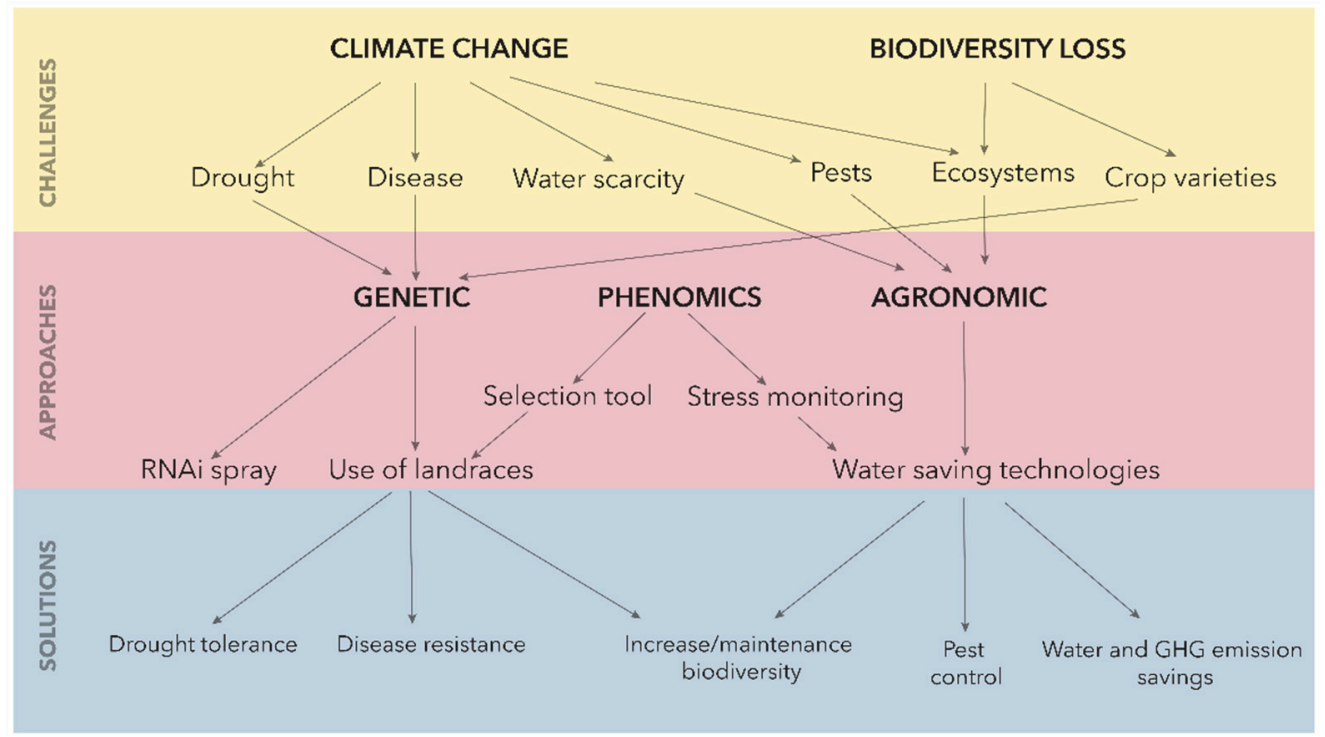

Figure 1. Main challenges, approaches, and proposed solutions of this review.

\section{Mitigation Strategy: Agronomic Approach}

Traditional water management associated with rice cropping in the Mediterranean Basin includes the permanent flooding of rice fields during most part of the year (AprilDecember). Traditional permanent flooding of rice fields uses large amounts of water and generate significant GHG emissions $[13,14]$ due to the anoxic conditions of submerged soils $[15,16]$. Therefore, alternative irrigation schemes have been proposed during the last decades to reduce water use and the impact of flooded rice on climate change. These new practices entail the drainage of water during different stages of the rice cycle when the impact of water shortage is expected to be less detrimental for crop performance. Alternate Wetting and Drying (AWD) is the most widely used water-saving technology worldwide and consists of alternate flooded and non-flooded periods during the growing and ripening stage of the rice cycle [17]. Previous studies indicate that the AWD strategy may save between $25 \%$ and $70 \%$ of water use [18] and reduces methane emissions from $30 \%$ to $90 \%[14,19,20]$, depending on the abiotic conditions of irrigated fields. Although less popular, other alternative water-saving technologies that entail a mid-season and/or a preharvest drying period have been also applied [21]. However, there is no consensus on the impact of these water-saving strategies on rice yield, as previous research has shown positive [22], negative [14,19,20,23-25], and neutral effects [14,23,26,27], depending on field conditions and rice cultivars. For example, Martínez-Eixarch et al. [14] found that AWD reduced methane emission by $90 \%$ when compared with the standard continuous flooding practice. Yet, the response of crop yield was cultivar-dependent, with one of the evaluated cultivars showing a tolerant response to water shortage while the other four cultivars suffered yield penalties.

Additional challenges in rice farming include coping with an increasing pest pressure associated to climate change [28]. Pest control is expected to increasingly depend on natural enemies of pests (i.e., biological pest control) as new EU agroenvironmental policies aim to reduce pesticide use by 50\% in 2030 [29]. In flooded rice, agroecosystems biological pest control largely relies on a broad range of aquatic organisms, such as predatory vertebrates (e.g., fishes and amphibians) and macroinvertebrates (e.g., diving beetles and dragonflies) [30,31]. The most relevant examples of such insect pests in the Mediterranean basin are nonbiting midges (Fam. Chironomidae) or Asiatic rice borers (Chilo supressalis, 
Fam. Crambidae). Nonbiting midges is a family of nematoceran flies with an aquatic larvae stage that damage rice seeds and rice roots, especially during the establishment of seedlings [32]. Aquatic animals such as amphibians, odonates, and other aquatic benthic macroinvertebrates (e.g., aquatic bugs and beetles) act as important predators of aquatic and terrestrial pests, including nonbiting midges that can entail important rice yield losses for local farmers and, also, vectors of important vector-borne diseases (e.g., mosquitoes). The high diversity of both amphibians and aquatic macroinvertebrates is thus expected to contribute in reducing pest pressure and rice damages, ultimately improving the rice yield. Alternative water management practices that entail one or more drying periods can act as ecological traps, reducing the diversity and/or the abundance of aquatic organisms and, thus, the effectiveness of biological control [30,31]. Therefore, water management strategies should account not only on yield impacts but also on the potential tradeoffs between water use savings and the conservation of aquatic biodiversity, especially in region areas where conservation is a priority.

\section{Adaptation Strategy: Genetic Approach}

In addition to agronomic measures such as the shift in planting dates, one of the most promising adaptation strategies to face climate change is the development of new cultivars better adapted to biotic and abiotic stresses. During the evolutionary history of wheat, its genetic diversity has suffered reductions in several steps of the domestication and breeding process [33]. The first step to obtain improved varieties is to generate variability, and this variability obtained from crosses of modern varieties (also known as "elite varieties") is nowadays limited. For this reason, landraces should be considered a key source of genetic resources to be exploited in the future [34]. Landraces may provide sources for adaptation, increased biomass, thousand kernel weight [33], drought tolerance [35], and disease resistance [36,37], among other benefits. The following are some innovative concepts provided to use landraces for coping with biotic and abiotic stress.

\subsection{Biotic Stresses}

Among cereal crops, fungal pathogens are a major threat. In particular, wheat is heavily attacked worldwide by rusts (leaf or brown rust caused by Puccinia triticina, yellow or stripe rust caused by P. striiformis f. sp. Tritici, and stem or black rust by P. graminis f. sp. tritici) and Septoria tritici blotch (caused by Zymoseptoria tritici), which can be responsible for huge yield losses, up to $70-80 \%$ in severe attacks, potentially threatening global food security [38]. There is also concern about global warming contributing to the movement of disease-causing agents into new territories [12,39]. At the same time, the world population is anticipated to reach 9.1 billion people in 2050, so agriculture should be ready to meet the global demand of food at affordable prices $[40,41]$. In this context, reducing crop losses caused by pests and diseases is a priority of the European Union (https:/ / data.worldbank.org/indicator, accessed on 20 November 2021).

Control of fungal diseases is based mainly on the use of fungicides, although breeding of resistant varieties contributes as well. In the last decades, intensive use of pesticides has contributed to yield increase but at high environmental costs such as the degradation of both biodiversity and biodiversity-mediated ecosystem services (e.g., biological pest control, nutrient cycling, pollination, etc.) [42-45]. Accordingly, the European Parliament and the Council of the European Union are taking action in order to reduce the use of pesticides and promote the search for new nonchemical approaches and alternatives to pesticide application [46]. In this new context, the application of the safest biotechnology in agriculture could play a key role to enlarge the range of tools for integrated and sustainable pest/disease management, which should be one of the cross-cutting priorities of a more sustainable agriculture [29]. The development of new varieties and of appropriate disease management strategies require a better understanding of pathogen virulence structure and of the divergence of races in different regions [47]. 
Yellow rust epidemics have been reported as an increasing problem all around the world, including the Mediterranean Basin [47,48]. It has been estimated that nearly $90 \%$ of world wheat production is threatened by this disease, and each year, about 5.5 million tons are lost, corresponding to losses of one billion dollars [49]. In the case of Spain, yellow rust was found first in 2008 and 2009 in some bread wheat cultivars in Northern Spain and spread heavily to the Southern and Eastern regions by 2013, where farmers had to treat bread wheat crops with fungicides to avoid severe yield losses [50]. The Global Rust Reference Center (GRRC) in Denmark [51] tested these Spanish yellow rust races and all matched the "Warrior" and "Warrior (-)" races, which had replaced previous European populations [52] due to its virulence on most bread wheat cultivars. Although bread wheat has been the most seriously affected crop by yellow rust infections, after 2013 some durum wheat varieties have also been affected in Southern of Spain. Yellow rust severity on durum wheat has been increasing, and the infection levels were similar to that on bread wheat in many regions by 2016. In 2018, a new yellow rust race named "PstS14" was detected in Spain [51]. Yellow rust infections are still present throughout Spain, although the importance of the infections decreased slightly by 2017 both in durum and bread wheat crops. The last screening performed by GRRC of Spanish isolates reported the presence of races "Warrior(-)" (with genotype "Pst10") and "PstS14" in Spain since 2019.

Leaf (brown) rust is the most widely extended of the three wheat rust diseases $[53,54]$. The average world losses have been estimated at 8.6 million metric tons and $\$ 1.5$ billion annually [55]. Leaf rust epidemics were not serious problems in bread wheat at the beginning of this century in Spain, as most bread wheat cultivars were resistant to leaf rust. However, even though durum wheat is generally considered more resistant to leaf rust than bread wheat, from the 2001-2002 season, leaf rust epidemics on durum wheat have been recorded at many locations in the Guadalquivir basin of Andalusia, and most local durum cultivars are susceptible. Martínez et al. [56] studied the virulence of 56 Andalusian leaf rust isolates collected from 1998 to 2000 on durum and bread wheat, and thirty-five different races were identified. Bread wheat races were different from durum wheat ones, being the first races more variable than those from durum wheat [57]. In addition, different genes were found in bread and durum wheat cultivars conferring rust resistance [58]. From 2004 onwards, rust attacks in Spain have begun to decrease due to the regular application of fungicides and the expansion of durum resistant cultivars, most of them basing their resistance on two genes ( $L r 72$ and $L r 14 a$ ). However, those genes did not prevent the appearance of a new virulent leaf rust in 2013 in Spain. This race was very similar to those reported in 2009-11 but with an added virulence to $L r 14 a$, and it was different from the reported French races virulent to $L r 14 a$ and avirulent to $L r 72$ [59]. This case emphasizes the dynamics and the complexity of rust diseases in wheat and the need for continuing investment in the development of new resistant cultivars at a faster pace than new pathogen appearances.

Wheat stem rust, caused by P. graminis f. sp. tritici (Pgt), is another one of the most devastating diseases of bread and durum wheat worldwide. Since the late 1950s, wheat crops have been effectively protected by the widespread use of host resistance and the eradication of the alternate host, common barberry (Berberis vulgaris L.), in the United States and Europe [60]. However, the emergence of new virulent pathogen races is posing a significant threat to wheat production worldwide. The occurrence and spread of Sr31virulent races in the Ug99 race group have incurred crop losses in East Africa and the Middle East [61,62]. Other races with significant virulence have caused severe epidemics and localized outbreaks in East Africa [63], Europe [64-66], Central Asia [67], and the Caucasus [68], indicating that the disease has reemerged as a major challenge to wheat production. In Spain, stem rust has been historically the most important rust disease of wheat, with several epidemics occurring in the 1940-1960 period [50]. Due to the adoption of shorter-cycle cultivars with improved resistance, stem rust has seldom been detected since the 1970s [50], but like in other European countries, infections started being observed in wheat fields in recent years and different races have been detected in Spain during the 
last three years [51]. There is an urgent need to devise a new integrative strategy to face the threat of stem rust in wheat in the face of climate change.

Z. tritici (originating Septoria tritici blotch) accounts for $70 \%$ of fungicide usage in the $\mathrm{EU}$, and yield losses can reach 50\% during severe epidemics [69]. Being a hemibiotrophic pathogen (switching from biotrophic to necrotrophic during the infection process) and with a complex life cycle including sexual reproduction [70], breeding strategies for resistance are difficult and usually involve partial (quantitative) resistance [71,72]. Additionally, plant height or heading time may interfere with the detection of resistance genes from landraces [36].

To reduce losses caused by plant pathogens, plant biologists have devised numerous methods to engineer resistant plants. Among them, RNA silencing-based resistance provides a powerful tool for engineering pest and disease resistant plants in the last two decades [73-76], opening new avenues for agrochemicals design. RNA silencing, referred to as gene quelling in fungi, post-transcriptional gene silencing (PTGS) in plants, and RNA interference (RNAi) in animals, is a conserved regulatory eukaryotic mechanism of gene expression that plays a crucial role in growth, development, and host defense [77,78]. The application of the RNAi technology is based on the delivery of double-stranded RNA (dsRNA) or small interfering RNA (siRNA) for gene silencing. Thus, RNAi can be considered as a natural gene-based technology for highly specific pest control. The use of RNAi in pest management has been widely studied in different organisms, showing the utility of this technology in both basic and applied science. For instance, the expression of dsRNAtargeting genes coding for MAP Kinase and cyclophilin in wheat plants caused a severe reduction of leaf rust infection by P. triticina [79]. However, due to political, legislative, and technical difficulties, transgenic crops have been difficult to introduce in some regions such as Europe. On the other hand, the present EU regulatory framework for plant protection does not hamper using dsRNA as external applications against pathogens [80]. Hence, topical application of dsRNA for pest control is emerging as an appealing alternative to genetically modified crops [81,82]. The rapid degradation of naked dsRNA limits its potential to trigger the RNAi mechanism, and this has been a major challenge towards its practical application. In general, dsRNA is much more stable than single-stranded RNA, but it must be rapidly taken up into the cells and digested into siRNA. Therefore, the use of nanomaterials as carriers to reduce dsRNA degradation and to increase the cellular uptake of intact dsRNA has gained relevance lately. Recently, Mitter et al. [83] demonstrated that dsRNA can be loaded on nontoxic, degradable, layered double hydroxide (LDH) clay nanosheets known as "BioClay". Once loaded on LDH, dsRNA does not wash off, shows sustainable release, and can be detected on sprayed leaves 30 days after application. Moreover, this study confirms that dsRNA could be translocated to untreated parts of the plant conferring protection even after a single spray. Biomimetic nano-apatite (a material similar to the bone mineral component) has been shown to be a promising nanomaterial used in nanomedicine [84]. Several studies have proven that they are completely nontoxic and biodegradable, two of the most important characteristics for becoming a smart delivery system $[85,86]$, and they can penetrate into wheat plants through the roots and leaves [87]. These traits make them suitable as nanocarriers in order to protect dsRNA from degradation, increasing its persistence and helping the penetration into plant and fungal tissues.

Traditionally, farmers select varieties in the field for their agronomic traits, but also, indirectly, they select for disease resistance. However, as cereal farming systems evolved, old landraces have been completely replaced with high-yielding cultivars. It is therefore necessary to use wheat landraces as one of the most promising sources of genetic resistance to different fungal diseases, as they could be donors of relevant new genes in current breeding programs. 


\subsection{Abiotic Stresses}

Mediterranean environments are suffering from water scarcity and heat stress that could only worsen in the future, thus constraining crop productivity [88]. Traditional varieties, also known as landraces, that were grown before the 20th Century are putatively adapted to those harsh conditions, depending on the site where they were cultivated. Most wheat varieties currently grown are the result of the so-called "Green Revolution". According to Norman Borlaug, this revolution started with the objective of obtaining new varieties with higher yields to alleviate poverty in Mexico and resistant to rusts, particularly stem rust [89]. The varieties produced during this period were not only rust-resistant but also photoperiod-insensitive and semi-dwarf, which made them very responsive to increased nitrogen fertilization without lodging. The Green Revolution led to increased yield levels in most wheat-producing countries [90], but they were bred under irrigation or in relatively high rainfall environments. Their success combined adequate mineral fertilization practices [91], plant protection, training, and other social improvements [89]. Plant breeding in the 21st century now faces the challenge to develop new crop cultivars able to maintain current yields but also resistant to drought and heat environments [92]. Gene flow from landraces to modern varieties has been historically uneven, with some subpopulations among the Mediterranean landraces underrepresented [93]. In rice, the last 50 years of breeding have differentially selected up to 200 genome regions linked to grain yield in modern cultivars [94].

Several studies have shown that genetic diversity of modern varieties is much lower than diversity from landraces [95-97]. The loss of crop genetic diversity, termed genetic erosion, is of great concern, particularly in face of climate change [98]. New varieties better adapted to harsher conditions will need sources of genetic variability that is not currently found in modern, established varieties [99]. During the change from landraces to modern varieties, some genome regions have become fixed, and breeders tend to make their crosses from a limited gene pool core of high-yielding varieties, thus further narrowing genetic variability [100]. For this reason, there have been calls pointing at the need to include landraces in the genetic background of cereal varieties in order to broaden their genetic diversity [101]. Due to their natures, landraces include some drought-tolerant genes that have been naturally selected over time [88]. Nowadays there are a few examples of landraces cultivated in some of the most unfavorable environments, where modern varieties are unadapted [99]. In rice, variations for some candidate genes responsible for canopy temperature and drought tolerance were found only within landraces adapted to droughtprone environments, but they are tall and low-yielding [102]. Landraces are usually adapted to harsh environments, namely drought and heat conditions; thus, they are suited to low input agriculture. Comparisons between landraces and modern varieties indicate that, in most cases, yields of the current varieties are higher than that of landraces, because most comparisons are made in favorable environments and under intensive agricultural practices $[103,104]$. The idea is not to substitute the best-adapted local varieties for landraces but to use the best landraces as a source of desirable genes for better adaptation to abiotic stress. Taken together, landraces of rice and wheat are characterized by low yield potential, photo-period sensitivity, late maturity, and sensitivity to lodging [105-107]. However, in extreme, low-yielding environments, some specific landraces outyield modern varieties, mainly in studies when only a few modern checks are used for comparison [108]. One of the problems of the current research on biodiversity is that, due to constraints in our working hypotheses, entries bearing rare alleles have to be eliminated from the statistical analysis of most studies. Rare alleles have shown, however, to be potentially very useful under specific conditions. For example, Vikram et al. [109] found that some groups of creole wheats from Mexico that were derived mostly from Spanish landraces were adapted to extreme environments and possessed several accumulated rare alleles [109].

As stated above, the direct use of landraces is not a viable scenario for adaptation to stress in most environments because of their low yield potential. Instead, new varieties should be bred with crosses between elite material and landraces. Breeding programs will 
need to incorporate valuable alleles to new varieties using pre-breeding approaches, this step being now considered critical [98]. The genes that confer adaptability to drought or heat environments could be deployed in breeding using conventional or molecular methods [88]. However, to make this breeding process a success, a large germplasm collection is required in order to locate suitable genes for drought tolerance for a particular target environment [100]. In some cases, such as yield under drought conditions, the interesting traits are not regulated by major genes but, rather, several QLTs with minor effects [104]. In those cases, finding genetic markers suitable for marker-assisted selection may present some practical challenges. The genomic selection methodology is rapidly improving, but the intrinsic variability that is needed to incorporate valuable genes from landraces may complicate the breeding process in practice. In those cases, indirect selection methods such as remote sensing would be of great value, either alone or in combination with genomic selection [110]. One of the latest and most promising technologies is genome editing [100], despite the fact that its use is highly regulated by law and putatively impossible to use in Europe and New Zealand [111]. However, this technology implies a deep knowledge of the desired genetic modification; that is, the exact gene, allele and target sequence the breeder needs. In case of cereal drought tolerance, most of the variability contained in landraces is still far from the point of being ready to use at genome editing level.

One drawback about the use of landraces in crosses is the introduction of genetic background with unwanted effects, also known as "linkage drag" [112]. To avoid it, the use of landraces should be included in a breeding strategy with an interdisciplinary approach with high efficiency and effectiveness in selection [113]. There is a general agreement that yield rises can only be achieved by improving the efficiency of large-scale breeding programs, particularly for suboptimal environments [114]. One of the major challenges of the breeding programs focusing on drought-prone areas is to develop tools capable of quantifying the actual water use of plants under different water regimes. The development of wheat and rice varieties with improved water use efficiency (yield per unit water used in transpiration) is seen as a way to raise yield in rainfed environments [115]. Other possible strategies to improve yields in water-limited environments would be breeding early cultivars that may avoid water deficits by completing their life cycle before severe water stress sets in. This strategy may be more viable in the future, as climate change might increase the chance of milder temperature winters in climates of terminal drought such as the Mediterranean. Avoidance of water deficits at the critical periods of flowering and early grain filling may be achieved by a combination of adequate cultivars sown early if reliable, medium-term weather predictions become available. Finally, supplemental or deficit irrigation may help boost yields where irrigation is feasible, provided cultivars of high yield potential are used to exploit the opportunity in years of ample water supply.

The major challenge for fast genetic progress is to connect genetic variants (genotype) to their expression in observable traits (phenotype) and to predict plant phenotypes from genetic information [116]. The enormous advances in genome sequencing of plants are providing massive genomic data collections, but the lack of efficient methods to collect rapid, high-quality, and high volumes of phenotypic data has become a bottleneck in genomics-assisted breeding [117-119]. It would be ideal to have fast and reliable phenomics tools to select for yield potential and drought tolerance in the earliest generations of the breeding program [120]. Such a selection tool would allow to: (1) increase the number of entries in the initial generations for each cross, thus improving the probability of favorable recombinant events, and (2) eliminate all unfavorable entries and retain the most promising ones very early in the breeding pipeline, thus allowing the breeder to devote more resources to evaluation of the promising selected entries in the later breeding phases.

\section{Phenomics Approach: Remote Sensing Technologies}

Due to the dynamic nature of plant growth, nondestructive imaging provides an important advance to understand growth in response to environmental factors such as distinct water availability in large numbers of genotypes with comparatively little effort [121]. 
Remote sensing for high-throughput phenotyping (HTP) is sparking an increased interest in the scientific and agricultural productive systems, particularly for applications in breeding and germplasm evaluation activities [117,122,123]. Field-based HTP through remote sensing allows the assessment of plant phenotypes on a scale and with a level of precision and speed impossible to be attained with traditional methods [124]. Many studies have used either RGB, fluorescent, thermal, hyperspectral, and 3D imaging to estimate morphological and physiological traits in multiple breeding programs and crops. Detailed, recent reviews have been published on remote sensing tools and platforms available for HTP on a plant breeding context [119,125-127].

The field phenotyping response of plants to soil available water and evaporative demand has had limited yield gains in breeding programs due to the difficulties of measuring actual transpiration or water status in a large number of plots. The evaluation of plant transpiration has relied mostly on surrogate traits, although this has most likely resulted in overdependence on the surrogates [128]. Leaf stomatal conductance (gs) is considered by some a critical physiological trait for increasing yield in both potential and water-limited conditions [129]. According to Roche [129], breeders by selecting for higher yields have inadvertently selected for high gs over the last decades. Stomatal conductance or some surrogates have been used extensively in wheat breeding programs, where it has shown potential as an early generation selection tool and throughout large breeding programs of wheat [130]. However, a gas exchange measurement of leaf gs is laborious, subjected to high variability among individual leaves, and requires experience.

As a higher conductance results in a reduction of canopy temperature (Tc), Tc has been used as a surrogate for gs. Many studies have demonstrated the remote sensing Vis capabilities for irrigation monitoring at the farm level [131,132]. Thus, Thermal and InfraRed (TIR)-based methodologies are increasingly being used to assess crop transpiration and water stress in annual crops and orchards [133-135]. For phenotyping, remote-sensed TIR imaging can determine plot temperatures within seconds, eliminating effects of the changes in the environment that occur with ground manual measurements, especially in large trials. Recent studies have demonstrated the high heritability obtained from Tc using direct measurements of the temperature as the trait of interest [136,137]. However, Tc is only a relative measurement of gs that is influenced by a number of factors such as solar radiation, wind speed, albedo, and canopy architecture. This constraint has been partially removed by the development of indices like the Crop Water Stress Index (CWSI), which is a method for normalizing environmental effects and vapor pressure deficits (VPD), in particular. Some authors $[138,139]$ have proposed its use as a phenotypic trait in combination with other indices obtained from multispectral sensors; however, comparisons between cultivars can only be achieved in a relative way. The CWSI is either calculated empirically through non-water stress baselines or using analytical equations or with reference panels. The use of the CWSI is complex, as the inherent phenotypic variability in traits affect the energy balance at the crop level: albedo, plant height, and architecture and, more importantly, stomatal response to VPD. These traits, which are different among cultivars, also evolve over time, depending on the crop phenological stage. The use of an analytical approach based on the energy balance $[133,140]$ can provide a more refined estimation of the actual physiological traits of interest, such as stomatal conductance or actual transpirations rates. If very high-resolution thermal imagery is available, it is possible to directly retrieve Tc and soil temperature, allowing the application of two source energy balance models that provide higher accuracies than simpler models $[132,141]$. Its combination with high resolution multispectral cameras can also provide estimates of key parameters for energy balance models, such as canopy height [142-144], ground cover [145], or even albedo [146].

In the case of evaluation against plant pathogens in breeding programs, traditional techniques involve in situ and in vitro observations of disease symptoms and the response of the crops against the attacking microorganism (resistance, susceptibility, etc.). Such observations usually present an antagonism between data recording the speed and accuracy and increasing one of those means while decreasing the other one. They require trained 
eyes and have an inherent human factor caused by the subjectivity of the observer. The application of sensing technologies for detecting specific phenotypic reactions occurring during plant-pathogen interactions offers new opportunities for elucidating the physiological mechanisms that link pathogen infection and disease symptoms in the host and also provide a faster approach in the selection of genetic material that is resistant to specific pathogens or strains. Appropriate phenomics methods and tools may also allow the presymptomatic detection of disease-related changes in plants or to identify changes that are not visually apparent [147].

The application of phenomics techniques to evaluate fungal leaf diseases in cereals under field conditions has been reported for a range of pathogens using different technologies, including RGB [148], hyperspectral or multispectral features [149-153], high-resolution multispectral imagery [154-156], and combinations of hyperspectral and physiological measurements [157]. In these studies, both ground and aerial observations have been used, and relatively good agreements between the standard visual assessments and model predictions are reported. The application of phenomics tools for screening and monitoring plant disease has been more widely adopted under controlled conditions and proximal sensing. Some tools have been developed to help breeders with the phenotyping of biotic stress [158]. Recently, an automated and open-source method named "PhenoBox" has been published and described [159] as a cost-effective alternative to complex automatic glasshouse systems. This system uses open-source plant imaging and processing and has been successfully tested for aerial plant pathogens and even abiotic (salinity) stress. Implementing and adapting this methodology to the study of wheat pathogens will allow for a more efficient and quick screening of selected genotypes under controlled conditions, reducing the time for evaluation and considering a larger number of variables with the high-throughput technique.

While the possibility of screening for plant disease is very attractive in a breeding program to scale up and assist in the selection of plant material more or less susceptible, phenotypic traits that influence the response of yield to disease, their genetic control, and the possible tradeoffs involved with other desirable agronomic characteristics are still very limited [160]. Although wheat crop losses due to foliar diseases have already been quantified with an ecophysiological approach, very few studies have analyzed the role of canopy architecture (light extinction coefficient-k value) and the vertical distribution of diseases into the canopy leaf layers [161]. Moreover, the ability of the plant to compensate for the reduced acquisition of resources by the production of new organs or by the remobilization of reserves may also mitigate biotic stress effects [162]. Therefore, understanding the effects of plant architecture in pathogen tolerance $[163,164]$ is critical and complements screening for susceptibility in breeding programs. However, the complexity of phenotyping for canopy architectural and complex physiological traits have impaired this approach. Nevertheless, the use of novel instrumentation such as the LiDAR can provide novel insights into traits related to radiation use efficiency and light distribution in the canopy [112,125]. Phenomobiles provide an ideal solution for delivering very high spatial and temporal resolutions and fill the gap between single plant measurements and the aerial phenotyping from UAVs or manned aircrafts [165], providing new opportunities for delivering complex traits such as stay green [166].

\section{Concluding Remarks}

Climate change presents an unprecedented challenge on the global scale that will only be overcome with the joint efforts of several disciplines, all of them highly specialized. Genetic knowledge of pathogen-host relationships will allow the development of RNAi spray methodologies to control diseases. This knowledge will also help in developing new cultivars using landraces bearing new resistance genes, drought tolerance, and increasing crop biodiversity. Phenomics tools will help breeding as a high-throughput, fast, and objective selection and stress monitoring tool. New water-saving technologies will help increase and maintain the biodiversity, which is basic for pest control, thereby saving 
water and GHG emissions avoiding yield decreases. Future progress in cereal production, particularly in suboptimal environments, will need to cover all the aspects discussed in this review jointly with other rapidly evolving technologies. The improvement of a single aspect of this global scenario will most probably fail in providing a satisfactory solution to the current and future challenges, and interdisciplinary works will be essential to improve the agricultural systems as a whole to ensure food security in the future.

Author Contributions: N.P.-M.: Conceptualization, funding acquisition, writing (original draft preparation and review and editing); C.M.-R.: Conceptualization, funding acquisition, writing (original draft preparation and review and editing); J.A.J.-B.: Conceptualization, funding acquisition, writing (original draft preparation and review and editing); D.G.-C.: Conceptualization, funding acquisition, writing (original draft preparation and review and editing); A.P.-d.-L.: Conceptualization, funding acquisition, writing (original draft preparation and review and editing); E.F.: Conceptualization, funding acquisition, writing (review and editing); M.C.-F.: Conceptualization, funding acquisition, writing (original draft preparation and review and editing); D.V.: Conceptualization, funding acquisition, writing (original draft preparation and review and editing); J.C.S.: Conceptualization, funding acquisition, writing (original draft preparation and review and editing). All authors have read and agreed to the published version of the manuscript.

Funding: This research was funded by Agencia Estatal de Investigación (Spain), grant numbers PID2020-118650RR-C31, PID2020-118650RR-C32, and PID2020-118650RR-C33. The authors affiliated with IRTA acknowledge the contribution of the CERCA program/Generalitat de Catalunya (http: / / cerca.cat; accessed on 20 November 2021). N. Pérez-Méndez was supported by the Juan de la Cierva- Incorporación program from the Ministry of Science and Innovation (Spain).

Institutional Review Board Statement: Not applicable.

Informed Consent Statement: Not applicable.

Data Availability Statement: Not applicable.

Acknowledgments: Thanks are given to Carmen Ávila for her contribution of ideas for the original version of this work.

Conflicts of Interest: The authors declare no conflict of interest. The funders had no role in the writing of the manuscript or in the decision to publish it.

\section{References}

1. FAOSTAT. FAOStat Database. 2021. Available online: https://www.fao.org/faostat/en/\#data (accessed on 20 November 2021).

2. Reeves, T.G.; Thomas, G.; Ramsay, G. Save and Grow in Practice: Maize, Rice, Wheat. A Guide to Sustainable Cereal Production; FAO UN: Rome, Italy, 2016; ISBN 9788578110796.

3. Snowdon, R.J.; Wittkop, B.; Chen, T.-W.; Stahl, A. Crop adaptation to climate change as a consequence of long-term breeding. Theor. Appl. Genet. 2021, 134, 1613-1623. [CrossRef] [PubMed]

4. Guzmán, C.; Autrique, J.E.; Mondal, S.; Singh, R.P.; Govindan, V.; Morales-Dorantes, A.; Posadas-Romano, G.; Crossa, J.; Ammar, K.; Peña, R.J. Response to drought and heat stress on wheat quality, with special emphasis on bread-making quality, in durum wheat. Field Crop. Res. 2016, 186, 157-165. [CrossRef]

5. Royo, C.; Elias, E.; Manthey, F. Durum Wheat Breeding. In Handbook of Plant Breeding: Cereals; Carena, M.J., Ed.; Springer: New York, NY, USA, 2009; pp. 199-226.

6. Arrúe, J.L.; Álvaro-Fuentes, J.; Plaza-Bonilla, D.; Villegas, D.; Cantero-Martínez, C. Managing drylands for sustainable agriculture. In Innovations in Sustainable Agriculture; Springer International Publishing: Cham, Switzerland, 2019; pp. 529-556.

7. Bouman, B.A.M.; Humphreys, E.; Tuong, T.P.; Barker, R. Rice and Water. In Advances in Agronomy; Sparks, D., Ed.; Academic Press: San Diego, CA, USA, 2007; pp. 187-237.

8. Giorgi, F.; Lionello, P. Climate change projections for the Mediterranean region. Glob. Planet. Chang. 2008, 63, 90-104. [CrossRef]

9. Asseng, S.; Cammarano, D.; Basso, B.; Chung, U.; Alderman, P.D.; Sonder, K.; Reynolds, M.; Lobell, D.B. Hot spots of wheat yield decline with rising temperatures. Glob. Chang. Biol. 2017, 23, 2464-2472. [CrossRef] [PubMed]

10. Caubel, J.; Launay, M.; Ripoche, D.; Gouache, D.; Buis, S.; Huard, F.; Huber, L.; Brun, F.; Bancal, M.O. Climate change effects on leaf rust of wheat: Implementing a coupled crop-disease model in a French regional application. Eur. J. Agron. 2017, 90, 53-66. [CrossRef]

11. Zittis, G.; Bruggeman, A.; Lelieveld, J. Revisiting future extreme precipitation trends in the Mediterranean. Weather Clim. Extrem. 2021, 34, 100380. [CrossRef]

12. Velásquez, A.C.; Castroverde, C.D.M.; He, S.Y. Plant-pathogen warfare under changing climate conditions. Curr. Biol. 2018, 28, R619-R634. [CrossRef] 
13. Martínez-Eixarch, M.; Alcaraz, C.; Viñas, M.; Noguerol, J.; Aranda, X.; Prenafeta-Boldú, F.X.; Saldaña-De la Vega, J.A.; Català, M.M.; Ibáñez, C. Neglecting the fallow season can significantly underestimate annual methane emissions in Mediterranean rice fields. PLoS ONE 2018, 13, e0202159. [CrossRef]

14. Martinez-Eixarch, M.; Alcaraz, C.; Guardia, M.; Catala-Forner, M.; Bertomeu, A.; Monaco, S.; Cochrane, N.; Oliver, V.; Teh, Y.A.; Courtois, B.; et al. Multiple environmental benefits of alternate wetting and drying irrigation system with limited yield impact on European rice cultivation: The Ebre Delta case. Agric. Water Manag. 2021, 258, 107164. [CrossRef]

15. Schütz, H.; Seiler, W.; Conrad, R. Processes involved in formation and emission of methane in rice paddies. Biogeochemistry 1989, 7, 33-53. [CrossRef]

16. Knox, S.H.; Matthes, J.H.; Sturtevant, C.; Oikawa, P.Y.; Verfaillie, J.; Baldocchi, D. Biophysical controls on interannual variability in ecosystem-scale CO 2 and CH 4 exchange in a California rice paddy. J. Geophys. Res. Biogeosci. 2016, 121, 978-1001. [CrossRef]

17. Rejesus, R.M.; Palis, F.G.; Rodriguez, D.G.P.; Lampayan, R.M.; Bouman, B.A.M. Impact of the alternate wetting and drying (AWD) water-saving irrigation technique: Evidence from rice producers in the Philippines. Food Policy 2011, 36, 280-288. [CrossRef]

18. Ishfaq, M.; Farooq, M.; Zulfiqar, U.; Hussain, S.; Akbar, N.; Nawaz, A.; Anjum, S.A.; Ahmad, S. Alternate wetting and drying: A water-saving and ecofriendly rice production system. Agric. Water Manag. 2020, 241, 106363. [CrossRef]

19. Linquist, B.A.; Anders, M.M.; Adviento-Borbe, M.A.A.; Chaney, R.L.; Nalley, L.L.; da Rosa, E.F.F.; van Kessel, C. Reducing greenhouse gas emissions, water use, and grain arsenic levels in rice systems. Glob. Chang. Biol. 2015, 21, 407-417. [CrossRef] [PubMed]

20. Liang, K.; Zhong, X.; Huang, N.; Lampayan, R.M.; Pan, J.; Tian, K.; Liu, Y. Grain yield, water productivity and $\mathrm{CH}_{4}$ emission of irrigated rice in response to water management in south China. Agric. Water Manag. 2016, 163, 319-331. [CrossRef]

21. FAO; ITPS. Recarbonizing Global Soils—A Technical Manual of Recommended Management Practices; FAO, Ed.; FAO: Rome, Italy, 2021; Volume 5, ISBN 978-92-5-134900-7.

22. Islam, S.M.M.; Gaihre, Y.K.; Shah, A.L.; Singh, U.; Sarkar, M.I.U.; Satter, M.A.; Sanabria, J.; Biswas, J.C.; Satter, M.A.; Sanabria, J.; et al. Rice yields and nitrogen use efficiency with different fertilizers and water management under intensive lowland rice cropping systems in Bangladesh. Nutr. Cycl. Agroecosystems 2016, 106, 143-156. [CrossRef]

23. Carrijo, D.R.; Akbar, N.; Reis, A.F.B.; Li, C.; Gaudin, A.C.M.; Parikh, S.J.; Green, P.G.; Linquist, B.A. Impacts of variable soil drying in alternate wetting and drying rice systems on yields, grain arsenic concentration and soil moisture dynamics. Field Crop. Res. 2018, 222, 101-110. [CrossRef]

24. Islam, S.M.; Gaihre, Y.K.; Biswas, J.C.; Jahan, M.S.; Singh, U.; Adhikary, S.K.; Satter, M.A.; Saleque, M.A. Different nitrogen rates and methods of application for dry season rice cultivation with alternate wetting and drying irrigation: Fate of nitrogen and grain yield. Agric. Water Manag. 2018, 196, 144-153. [CrossRef]

25. Islam, S.F.; van Groenigen, J.W.; Jensen, L.S.; Sander, B.O.; de Neergaard, A.; Faiz-ul Islama, S.; van Groenigen, J.W.; Jensen, L.S.; Sander, B.O.; de Neergaard, A. The effective mitigation of greenhouse gas emissions from rice paddies without compromising yield by early-season drainage. Sci. Total Environ. 2018, 612, 1329-1339. [CrossRef] [PubMed]

26. Runkle, B.R.K.; Suvoscarev, K.; Reba, M.L.; Reavis, C.W.; Smith, S.F.; Chiu, Y.-L.; Fong, B.; Suvočarev, K.; Reba, M.L.; Reavis, C.W.; et al. Methane emission reductions from the alternate wetting and drying of rice fields detected using the eddy covariance method. Environ. Sci. Technol. 2019, 53, 671-681. [CrossRef]

27. Liao, B.; Wu, X.; Yu, Y.; Luo, S.; Hu, R.; Lu, G. Effects of mild alternate wetting and drying irrigation and mid-season drainage on $\mathrm{CH} 4$ and N2O emissions in rice cultivation. Sci. Total Environ. 2020, 698, 134212. [CrossRef] [PubMed]

28. Deutsch, C.A.; Tewksbury, J.J.; Tigchelaar, M.; Battisti, D.S.; Merrill, S.C.; Huey, R.B.; Naylor, R.L. Increase in crop losses to insect pests in a warming climate. Science 2018, 361, 916-919. [CrossRef] [PubMed]

29. European Commission. Sustainable Use of Pesticides. 2020. Available online: https://ec.europa.eu/food/plants/pesticides/ sustainable--use--pesticides_en (accessed on 28 December 2021).

30. Finlayson, C.M.; Milton, G.R.; Prentice, R.C.; Davidson, N.C. The Wetland Book; Finlayson, C.M., Milton, G.R., Prentice, R.C., Davidson, N.C., Eds.; Springer: Dordrecht, The Netherlands, 2018; Volume 3, ISBN 9789400740013.

31. Keddy, P.A. Wetland Ecology. Principles and Conservation, 2nd ed.; Keddy, P.A., Ed.; Cambridge University Press: New York, NY, USA, 2010; ISBN 9780521519403

32. Català, M.M.; Mayor, E.P.; Martínez-Eixarch, M.; Navarro, N.T.; Torrá, I. El manejo del agua: Estrategia de control de quironómidos en arrozales del delta del Ebro. Agric. Rev. Agropecu. Ganad. 2011, 941, 394-395.

33. Lopes, M.S.; El-Basyoni, I.; Baenziger, P.S.; Singh, S.; Royo, C.; Ozbek, K.; Aktas, H.; Ozer, E.; Ozdemir, F.; Manickavelu, A.; et al. Exploiting genetic diversity from landraces in wheat breeding for adaptation to climate change. J. Exp. Bot. 2015, 66, 3477-3486. [CrossRef] [PubMed]

34. Taranto, F.; D’Agostino, N.; Rodriguez, M.; Pavan, S.; Minervini, A.P.; Pecchioni, N.; Papa, R.; De Vita, P. Whole genome scan reveals molecular signatures of divergence and selection related to important traits in durum wheat germplasm. Front. Genet. 2020, 11, 217. [CrossRef] [PubMed]

35. Roselló, M.; Villegas, D.; Álvaro, F.; Soriano, J.M.; Lopes, M.S.; Nazco, R.; Royo, C. Unravelling the relationship between adaptation pattern and yield formation strategies in Mediterranean durum wheat landraces. Eur. J. Agron. 2019, 107, 43-52. [CrossRef]

36. Ouaja, M.; Aouini, L.; Bahri, B.; Ferjaoui, S.; Medini, M.; Marcel, T.C.; Hamza, S. Identification of valuable sources of resistance to Zymoseptoria tritici in the Tunisian durum wheat landraces. Eur. J. Plant Pathol. 2020, 156, 647-661. [CrossRef] 
37. Elbasyoni, I.S.; El-Orabey, W.M.; Morsy, S.; Baenziger, P.S.; Al Ajlouni, Z.; Dowikat, I. Evaluation of a global spring wheat panel for stripe rust: Resistance loci validation and novel resources identification. PLoS ONE 2019, 14, e0222755. [CrossRef]

38. Flood, J. The importance of plant health to food security. Food Secur. 2010, 2, 215-231. [CrossRef]

39. Bebber, D.P.; Ramotowski, M.A.T.; Gurr, S.J. Crop pests and pathogens move polewards in a warming world. Nat. Clim. Chang. 2013, 3, 985-988. [CrossRef]

40. Edmeades, G.O.; Fisher, R.A.; Byerlee, D. Can we feed the world in 2050? Proc. N. Z. Grassl. Assoc. 2010, 13, 36-42. [CrossRef]

41. FAO. How to Feed the World in 2050. 2009. Available online: https://www.fao.org/fileadmin/templates/wsfs/docs/expert_ paper/How_to_Feed_the_World_in_2050.pdf (accessed on 28 December 2021).

42. Fisher, A.; Coleman, C.; Hoffmann, C.; Fritz, B.; Rangel, J.; Fisher II, A.; Coleman, C.; Hoffmann, C.; Fritz, B.; Rangel, J. The synergistic effects of almond protection fungicides on honey bee (Hymenoptera: Apidae) forager survival. J. Econ. Entomol. 2017, 110, 802-808. [CrossRef] [PubMed]

43. Simon-Delso, N.; Martin, G.S.; Bruneau, E.; Hautier, L. Time-to-death approach to reveal chronic and cumulative toxicity of a fungicide for honeybees not revealed with the standard ten-day test. Sci. Rep. 2018, 8, 7241. [CrossRef] [PubMed]

44. Brauman, K.A.; Garibaldi, L.A.; Polasky, S.; Aumeeruddy-Thomas, Y.; Brancalion, P.H.S.; DeClerck, F.; Jacob, U.; Mastrangelo, M.E.; Nkongolo, N.V.; Palang, H.; et al. Global trends in nature's contributions to people. Proc. Natl. Acad. Sci. USA 2020, 117, 32799-32805. [CrossRef]

45. IPBES. Summary for Policymakers of the Global Assessment Report on Biodiversity and Ecosystem Services of the Intergovernmental Science-Policy Platform on Biodiversity and Ecosystem Services; IPBES Secretariat: Bonn, Germany, 2019; ISBN 9783947851133.

46. European Comission. Communication from the Commission to the European Parliament, the Council, the European Economic and Social Committee and the Committee of the Regions: A Farm to Fork Strategy for a Fair, Healthy and Environmentally-Friendly Food System COM/2020/381 Final; European Commission: Brussels, Belgium, 2020.

47. Ali, S.; Rodriguez-Algaba, J.; Thach, T.; Sørensen, C.K.; Hansen, J.G.; Lassen, P.; Nazari, K.; Hodson, D.P.; Justesen, A.F.; Hovmøller, M.S. Yellow rust epidemics worldwide were caused by pathogen races from divergent genetic lineages. Front. Plant Sci. 2017, 8 , 1057. [CrossRef]

48. Hovmøller, M.S.; Walter, S.; Justesen, A.F. Escalating threat of wheat rusts. Science 2010, 329, 369. [CrossRef] [PubMed]

49. Beddow, J.M.; Pardey, P.G.; Chai, Y.; Hurley, T.M.; Kriticos, D.J.; Braun, H.-J.; Park, R.F.; Cuddy, W.S.; Yonow, T. Research investment implications of shifts in the global geography of wheat stripe rust. Nat. Plants 2015, 1, 15132. [CrossRef] [PubMed]

50. Martinez-Moreno, F.; Solis, I. Wheat rust evolution in Spain: An historical review. Phytopathol. Mediterr. $2019,58,3-16$.

51. GRRC. 2021. Available online: https:/ / wheatrust.org (accessed on 20 November 2021).

52. Hovmøller, M.S.; Walter, S.; Bayles, R.A.; Hubbard, A.; Flath, K.; Sommerfeldt, N.; Leconte, M.; Czembor, P.; Rodriguez-Algaba, J.; Thach, T.; et al. Replacement of the European wheat yellow rust population by new races from the centre of diversity in the near-Himalayan region. Plant Pathol. 2016, 65, 402-411. [CrossRef]

53. Bolton, M.D.; Kolmer, J.A.; Garvin, D.F. Wheat leaf rust caused by Puccinia triticina. Mol. Plant Pathol. 2008, 9, 563-575. [CrossRef] [PubMed]

54. Huerta-Espino, J.; Singh, R.P.; German, S.; McCallum, B.D.; Park, R.F.; Chen, W.Q.; Bhardwaj, S.C.; Goyeau, H. Global status of wheat leaf rust caused by Puccinia triticina. Euphytica 2011, 179, 143-160. [CrossRef]

55. Chai, Y.; Pardey, P.G.; Hurley, T.M.; Senay, S.D.; Beddow, J.M. A probabilistic bio-economic assessment of the global consequences of wheat leaf rust. Phytopatology 2020, 110, 1886-1896. [CrossRef] [PubMed]

56. Martinez, F.; Sillero, J.C.; Rubiales, D. Pathogenic Specialization of Puccinia triticina in Andalusia from 1998 to 2000. J. Phytopathol. 2005, 153, 344-349. [CrossRef]

57. Kolmer, J. Leaf rust of wheat: Pathogen biology, variation and host resistance. Forests 2013, 4, 70-84. [CrossRef]

58. Martínez, F.; Sillero, J.C.; Rubiales, D. Resistance to leaf rust in cultivars of bread wheat and durum wheat grown in Spain. Plant Breed. 2007, 126, 13-18. [CrossRef]

59. Soleiman, N.H.; Solis, I.; Soliman, M.H.; Sillero, J.C.; Villegas, D.; Alvaro, F.; Royo, C.; Serra, J.; Ammar, K.; Martínez-Moreno, F. Emergence of a new race of leaf rust with combined virulence to Lr14a and Lr72 genes on durum wheat. Spanish J. Agric. Res. 2016, 14, e10SC02. [CrossRef]

60. Roelfs, A.P. Wheat and rye stem rust. In Diseases, Distribution, Epidemiology, and Control; Elsevier: Amsterdam, The Netherlands, 1985; pp. 3-37.

61. Pretorius, Z.A.; Singh, R.P.; Wagoire, W.W.; Payne, T.S. Detection of virulence to wheat stem rust resistance gene Sr31 in Puccinia graminis f. sp. tritici in Uganda. Plant Dis. 2000, 84, 203. [CrossRef] [PubMed]

62. Singh, R.P.; Hodson, D.P.; Jin, Y.; Lagudah, E.S.; Ayliffe, M.A.; Bhavani, S.; Rouse, M.N.; Pretorius, Z.A.; Szabo, L.J.; Huerta-Espino, J.; et al. Emergence and spread of new races of wheat stem rust fungus: Continued threat to food security and prospects of genetic control. Phytopathology 2015, 105, 872-884. [CrossRef]

63. Olivera, P.; Newcomb, M.; Szabo, L.J.; Rouse, M.; Johnson, J.; Gale, S.; Luster, D.G.; Hodson, D.; Cox, J.A.; Burgin, L.; et al. Phenotypic and genotypic characterization of race TKTTF of Puccinia graminis f. sp. tritici that caused a wheat stem rust epidemic in southern Ethiopia in 2013-2014. Phytopathology 2015, 105, 917-928. [CrossRef]

64. Bhattacharya, S. Wheat rust back in Europe. Nature 2017, 542, 145-146. [CrossRef] 
65. Firpo, P.D.O.; Newcomb, M.; Flath, K.; Sommerfeldt-Impe, N.; Szabo, L.J.; Carter, M.; Luster, D.G.; Jin, Y. Characterization of Puccinia graminis f. sp. tritici isolates derived from an unusual wheat stem rust outbreak in Germany in 2013. Plant Pathol. 2017, 66, 1258-1266. [CrossRef]

66. Lewis, C.M.; Persoons, A.; Bebber, D.P.; Kigathi, R.N.; Maintz, J.; Findlay, K.; Bueno-Sancho, V.; Corredor-Moreno, P.; Harrington, S.A.; Kangara, N.; et al. Potential for re-emergence of wheat stem rust in the United Kingdom. Commun. Biol. $2018,1,13$. [CrossRef]

67. Shamanin, V.P.; Pototskaya, I.V.; Shepelev, S.S.; Pozherukova, V.E.; Salina, E.A.; Skolotneva, E.S.; Hodson, D.; Hovmøller, M.; Patpour, M.; Morgounov, A.I. Stem rust in Western Siberia-Race composition and effective resistance genes. Vavilov J. Genet. Breed. 2020, 24, 131-138. [CrossRef] [PubMed]

68. Olivera, P.D.; Sikharulidze, Z.; Dumbadze, R.; Szabo, L.J.; Newcomb, M.; Natsarishvili, K.; Rouse, M.N.; Luster, D.G.; Jin, Y. Presence of a sexual population of Puccinia graminis f. sp. tritici in Georgia provides a hotspot for genotypic and phenotypic diversity. Phytopathology 2019, 109, 2152-2160. [CrossRef] [PubMed]

69. Fones, H.; Gurr, S. The impact of Septoria tritici blotch disease on wheat: An EU perspective. Fungal Genet. Biol. $2015,79,3-7$. [CrossRef]

70. Steinberg, G. Cell biology of Zymoseptoria tritici: Pathogen cell organization and wheat infection. Fungal Genet. Biol. 2015, 79, 17-23. [CrossRef]

71. Arraiano, L.S.; Brown, J.K.M. Sources of resistance and susceptibility to Septoria tritici blotch of wheat. Mol. Plant Pathol. 2017, 18, 276-292. [CrossRef]

72. Kidane, Y.G.; Hailemariam, B.N.; Mengistu, D.K.; Fadda, C.; Pè, M.E.; Dell'Acqua, M.; Pe, M.E.; Dell'Acqua, M. Genome-wide association study of Septoria tritici blotch resistance in Ethiopian durum wheat landraces. Front. Plant Sci. 2017, $8,1586$. [CrossRef]

73. Koch, A.; Kumar, N.; Weber, L.; Keller, H.; Imani, J.; Kogel, K.-H. Host-induced gene silencing of cytochrome P450 lanosterol C14 $\alpha$-demethylase-encoding genes confers strong resistance to Fusarium species. Proc. Natl. Acad. Sci. USA 2013, 110, 19324-19329. [CrossRef] [PubMed]

74. Duan, C.-G.; Wang, C.-H.; Guo, H.-S. Application of RNA silencing to plant disease resistance. Silence 2012, 3, 5. [CrossRef]

75. Werner, B.T.; Gaffar, F.Y.; Schuemann, J.; Biedenkopf, D.; Koch, A.M. RNA-Spray-mediated silencing of Fusarium graminearum AGO and DCL genes improve barley disease resistance. Front. Plant Sci. 2020, 11, 476. [CrossRef]

76. Cagliari, D.; Dias, N.P.; Galdeano, D.M.; dos Santos, E.Á.; Smagghe, G.; Zotti, M.J. Management of pest insects and plant diseases by non-transformative RNAi. Front. Plant Sci. 2019, 10, 1319. [CrossRef]

77. Burand, J.P.; Hunter, W.B. RNAi: Future in insect management. J. Invertebr. Pathol. 2013, 112, S68-S74. [CrossRef]

78. Maillard, P.V.; Ciaudo, C.; Marchais, A.; Li, Y.; Jay, F.; Ding, S.W.; Voinnet, O. Antiviral RNA interference in mammalian cells. Science 2013, 342, 235-238. [CrossRef]

79. Panwar, V.; Jordan, M.; McCallum, B.; Bakkeren, G. Host-induced silencing of essential genes in Puccinia triticina through transgenic expression of RNAi sequences reduces severity of leaf rust infection in wheat. Plant Biotechnol. J. 2018, 16, 1013-1023. [CrossRef]

80. Dietz-Pfeilstetter, A.; Mendelsohn, M.; Gathmann, A.; Klinkenbuß, D.; Klinkenbuss, D. Considerations and regulatory approaches in the USA and in the EU for dsRNA-based externally applied pesticides for plant protection. Front. Plant Sci. 2021, 12, 974. [CrossRef]

81. Marcianò, D.; Ricciardi, V.; Fassolo, E.M.; Passera, A.; Bianco, P.A.; Failla, O.; Casati, P.; Maddalena, G.; De Lorenzis, G.; Toffolatti, S.L.; et al. RNAi of a putative grapevine susceptibility gene as a possible downy mildew control strategy. Front. Plant Sci. 2021, 12, 667319. [CrossRef]

82. Haile, Z.M.; Gebremichael, D.E.; Capriotti, L.; Molesini, B.; Negrini, F.; Collina, M.; Sabbadini, S.; Mezzetti, B.; Baraldi, E. Double-stranded RNA targeting dicer-like genes compromises the pathogenicity of Plasmopara viticola on grapevine. Front. Plant Sci. 2021, 12, 667539. [CrossRef]

83. Mitter, N.; Worrall, E.A.; Robinson, K.E.; Li, P.; Jain, R.G.; Taochy, C.; Fletcher, S.J.; Carroll, B.J.; Lu, G.Q.; Xu, Z.P. Clay nanosheets for topical delivery of RNAi for sustained protection against plant viruses. Nat. Plants 2017, 3, 16207. [CrossRef] [PubMed]

84. Iafisco, M.; Delgado-López, J. Apatite: Synthesis, Structural Characterization, and Biomedical Applications; Nova Science Publishers: Hauppauge, NY, USA, 2014.

85. Sandhöfer, B.; Meckel, M.; Delgado-López, J.M.; Patrício, T.; Tampieri, A.; Rösch, F.; Iafisco, M. Synthesis and preliminary in vivo evaluation of well-dispersed biomimetic nanocrystalline apatites labeled with positron emission tomographic imaging agents. ACS Appl. Mater. Interfaces 2015, 7, 10623-10633. [CrossRef]

86. Pérez-de-Luque, A. Interaction of nanomaterials with plants: What do we need for real applications in agriculture? Front. Environ. Sci. 2017, 5, 12. [CrossRef]

87. Ramírez-Rodríguez, G.B.; Miguel-Rojas, C.; Montanha, G.S.; Carmona, F.J.; Dal Sasso, G.; Sillero, J.C.; Skov Pedersen, J.; Masciocchi, N.; Guagliardi, A.; Pérez-de-Luque, A.; et al. Reducing nitrogen dosage in Triticum durum plants with urea-doped nanofertilizers. Nanomaterials 2020, 10, 1043. [CrossRef]

88. Rosero, A.; Granda, L.; Berdugo-Cely, J.A.; Šamajová, O.; Šamaj, J.; Cerkal, R.; Samajova, O.; Samaj, J.; Cerkal, R. A dual strategy of breeding for drought tolerance and introducing drought-tolerant, underutilized crops into production systems to enhance their resilience to water deficiency. Plants 2020, 9, 1263. [CrossRef] 
89. Borlaug, N.E. Sixty-two years of fighting hunger: Personal recollections. Euphytica 2007, 157, 287-297. [CrossRef]

90. Fischer, R.A.; Connor, D.J. Issues for cropping and agricultural science in the next 20 years. Field Crop. Res. 2018, 222, 121-142. [CrossRef]

91. Pingali, P.L. Green revolution: Impacts, limits, andthe path ahead. Proc. Natl. Acad. Sci. USA 2012, 109, 12302-12308. [CrossRef]

92. Pascual, L.; Ruiz, M.; López-Fernández, M.; Pérez-Penã, H.; Benavente, E.; Vázquez, J.F.; Sansaloni, C.; Giraldo, P. Genomic analysis of Spanish wheat landraces reveals their variability and potential for breeding. BMC Genom. 2020, 21, 122. [CrossRef] [PubMed]

93. Soriano, J.M.; Sansaloni, C.; Ammar, K.; Royo, C. Labelling selective wweeps used in durum wheat breeding from a diverse and structured panel of landraces and cultivars. Biology 2021, 10, 258. [CrossRef]

94. Xie, W.; Wang, G.; Yuan, M.; Yao, W.; Lyu, K.; Zhao, H.; Yang, M.; Li, P.; Zhang, X.; Yuan, J.; et al. Breeding signatures of rice improvement revealed by a genomic variation map from a large germplasm collection. Proc. Natl. Acad. Sci. USA 2015, 112, E5411-E5419. [CrossRef]

95. Cavanagh, C.R.; Chao, S.M.; Wang, S.C.; Huang, B.E.; Stephen, S.; Kiani, S.; Forrest, K.; Saintenac, C.; Brown-Guedira, G.L.; Akhunova, A.; et al. Genome-wide comparative diversity uncovers multiple targets of selection for improvement in hexaploid wheat landraces and cultivars. Proc. Natl. Acad. Sci. USA 2013, 110, 8057-8062. [CrossRef] [PubMed]

96. Kyratzis, A.C.; Nikoloudakis, N.; Katsiotis, A. Genetic variability in landraces populations and the risk to lose genetic variation. The example of landrace "Kyperounda" and its implications for ex situ conservation. PLoS ONE 2019, 14, e0224255. [CrossRef] [PubMed]

97. Newton, A.C.; Akar, T.; Baresel, J.P.; Bebeli, P.J.; Bettencourt, E.; Bladenopoulos, K.V.; Czembor, J.H.; Fasoula, D.A.; Katsiotis, A.; Koutis, K.; et al. Cereal landraces for sustainable agriculture. Sustain. Agric. 2009, 2, 147-186. [CrossRef]

98. Khoury, C.K.; Brush, S.; Costich, D.E.; Curry, H.A.; Haan, S.; Engels, J.M.M.; Guarino, L.; Hoban, S.; Mercer, K.L.; Miller, A.J.; et al. Crop genetic erosion: Understanding and responding to loss of crop diversity. New Phytol. 2022, 233, 84-118. [CrossRef]

99. Marone, D.; Russo, M.A.; Mores, A.; Ficco, D.B.M.; Laidò, G.; Mastrangelo, A.M.; Borrelli, G.M. Importance of landraces in cereal breeding for stress tolerance. Plants 2021, 10, 1267. [CrossRef]

100. Khadka, K.; Raizada, M.N.; Navabi, A. Recent progress in germplasm evaluation and gene mapping to enable breeding of drought-tolerant wheat. Front. Plant Sci. 2020, 11, 1149. [CrossRef] [PubMed]

101. Leisova-Svobodova, L.; Chrpova, J.; Hermuth, J.; Dotlacil, L. Quo vadis wheat breeding: A case study in Central Europe. Euphytica 2020, 216, 141. [CrossRef]

102. Melandri, G.; Prashar, A.; McCouch, S.R.; van der Linden, G.; Jones, H.G.; Kadam, N.; Jagadish, K.; Bouwmeester, H.; Ruyter-Spira, C. Association mapping and genetic dissection of drought-induced canopy temperature differences in rice. J. Exp. Bot. 2020, 71, 1614-1627. [CrossRef] [PubMed]

103. Royo, C.; Ammar, K.; Villegas, D.; Soriano, J.M.M. Agronomic, physiological and genetic changes associated with evolution, migration and modern breeding in durum wheat. Front. Plant Sci. 2021, 12, 1318. [CrossRef]

104. Salsman, E.; Liu, Y.; Hosseinirad, S.A.; Kumar, A.; Manthey, F.; Elias, E.; Li, X. Assessment of genetic diversity and agronomic traits of durum wheat germplasm under drought environment of the northern Great Plains. Crop Sci. 2021, 61, 1194-1206. [CrossRef]

105. Gaur, V.S.; Channappa, G.; Chakraborti, M.; Sharma, T.R.; Mondal, T.K. 'Green revolution' dwarf gene sd1 of rice has gigantic impact. Brief. Funct. Genom. 2020, 19, 390-409. [CrossRef]

106. Royo, C.; Álvaro, F.; Martos, V.; Ramdani, A.; Isidro, J.; Villegas, D.; García del Moral, L.F. Genetic changes in durum wheat yield components and associated traits in Italian and Spanish varieties during the 20th century. Euphytica 2007, 155, 259-270. [CrossRef]

107. Sanchez-Garcia, M.; Álvaro, F.; Martín-Sánchez, J.A.; Sillero, J.C.; Escribano, J.; Royo, C. Breeding effects on the genotype $\times$ environment interaction for yield of bread wheat grown in Spain during the 20th century. Field Crop. Res. 2012, 126, 79-86. [CrossRef]

108. Kabbaj, H.; Sall, A.T.; Al-Abdallat, A.; Geleta, M.; Amri, A.; Filali-Maltouf, A.; Belkadi, B.; Ortiz, R.; Bassi, F.M. Genetic diversity within a global panel of durum wheat (Triticum durum) landraces and modern germplasm reveals the history of alleles exchange. Front. Plant Sci. 2017, 8, 1277. [CrossRef] [PubMed]

109. Vikram, P.; Franco, J.; Burgueño-Ferreira, J.; Li, H.; Sehgal, D.; Saint Pierre, C.; Ortiz, C.; Sneller, C.; Tattaris, M.; Guzman, C.; et al. Unlocking the genetic diversity of Creole wheats. Sci. Rep. 2016, 6, 23092. [CrossRef] [PubMed]

110. Crain, J.; Mondal, S.; Rutkoski, J.; Singh, R.P.; Poland, J. Combining high-throughput phenotyping and genomic information to increase prediction and selection accuracy in wheat breeding. Plant Genome 2018, 11, 170043. [CrossRef]

111. Gupta, S.; Kumar, A.; Patel, R.; Kumar, V. Genetically modified crop regulations: Scope and opportunity using the CRISPR-Cas9 genome editing approach. Mol. Biol. Rep. 2021, 48, 4851-4863. [CrossRef]

112. Jimenez-Berni, J.A.; Deery, D.M.; Rozas-Larraondo, P.; Condon, A.T.G.; Rebetzke, G.J.; James, R.A.; Bovill, W.D.; Furbank, R.T.; Sirault, X.R.R.R. High throughput determination of plant height, ground cover, and above-ground biomass in wheat with LiDAR. Front. Plant Sci. 2018, 9, 237. [CrossRef] [PubMed]

113. De Vita, P.; Taranto, F. Durum Wheat (Triticum turgidum ssp. durum) Breeding to Meet the Challenge of Climate Change; AlKhayri, J.M., Jain, S.M., Johnson, D.V., Eds.; Springer: Cham, Switzerland, 2019; ISBN 978-3-030-23108-8.

114. Moshelion, M.; Altman, A. Current challenges and future perspectives of plant and agricultural biotechnology. TRENDS Biotechnol. 2015, 33, 337-342. [CrossRef] 
115. Condon, A.G.; Richards, R.A.; Rebetzke, G.J.; Farquhar, G.D. Breeding for high water-use efficiency. J. Exp. Bot. 2004, 55, 2447-2460. [CrossRef]

116. Cobb, J.N.; DeClerck, G.; Greenberg, A.; Clark, R.; McCouch, S. Next-generation phenotyping: Requirements and strategies for enhancing our understanding of genotype-phenotype relationships and its relevance to crop improvement. Theor. Appl. Genet. 2013, 126, 867-887. [CrossRef]

117. Furbank, R.T.; Tester, M. Phenomics-Technologies to relieve the phenotyping bottleneck. Trends Plant Sci. 2011, 16, 635-644. [CrossRef]

118. White, J.W.; Andrade-Sanchez, P.; Gore, M.A.; Bronson, K.F.; Coffelt, T.A.; Conley, M.M.; Feldmann, K.A.; French, A.N.; Heun, J.T.; Hunsaker, D.J.; et al. Field-based phenomics for plant genetics research. Field Crop. Res. 2012, 133, 101-112. [CrossRef]

119. Araus, J.L.; Kefauver, S.C.; Zaman-Allah, M.; Olsen, M.S.; Cairns, J.E. Translating high-throughput phenotyping into genetic gain. Trends Plant Sci. 2018, 23, 451-466. [CrossRef] [PubMed]

120. Krause, M.R.; Mondal, S.; Crossa, J.; Singh, R.P.; Pinto, F.; Haghighattalab, A.; Shrestha, S.; Rutkoski, J.; Gore, M.A.; Sorrells, M.E.; et al. Aerial high-throughput phenotyping enables indirect selection for grain yield at the early generation, seed-limited stages in breeding programs. Crop Sci. 2020, 60, 3096-3114. [CrossRef]

121. Berger, B.; Parent, B.; Tester, M. High-throughput shoot imaging to study drought responses. J. Exp. Bot. 2010, 61, 3519-3528. [CrossRef]

122. Fiorani, F.; Schurr, U. Future scenarios for plant phenotyping. In Annual Review of Plant Biology; Merchant, S.S., Ed.; Annual Reviews: Palo Alto, CA, USA, 2013; Volume 64, pp. 267-291. ISBN 1543-5008.

123. Walter, A.; Liebisch, F.; Hund, A. Plant phenotyping: From bean weighing to image analysis. Plant Methods 2015, 11, 14. [CrossRef]

124. Dhondt, S.; Wuyts, N.; Inze, D.; Inzé, D. Cell to whole-plant phenotyping: The best is yet to come. Trends Plant Sci. 2013, 18, 433-444. [CrossRef] [PubMed]

125. Furbank, R.T.; Jimenez-Berni, J.A.; George-Jaeggli, B.; Potgieter, A.B.; Deery, D.M.; Jimenez-Berni, J.A.; George-Jaeggli, B.; Potgieter, A.B.; Deery, D.M. Field crop phenomics: Enabling breeding for radiation use efficiency and biomass in cereal crops. New Phytol. 2019, 223, 1714-1727. [CrossRef]

126. Roitsch, T.; Cabrera-Bosquet, L.L.; Fournier, A.; Ghamkhar, K.; Jiménez-Berni, J.; Pinto, F.; Ober, E.S.; Jimenez-Berni, J.; Pinto, F.; Ober, E.S. Review: New sensors and data-driven approaches-A path to next generation phenomics. Plant Sci. 2019, $282,2-10$. [CrossRef] [PubMed]

127. Araus, J.L.; Cairns, J.E. Field high-throughput phenotyping: The new crop breeding frontier. Trends Plant Sci. 2014, 19, 52-61. [CrossRef]

128. Vadez, V.; Kholova, J.; Medina, S.; Kakkera, A.; Anderberg, H. Transpiration efficiency: New insights into an old story. J. Exp. Bot. 2014, 65, 6141-6153. [CrossRef]

129. Roche, D. Stomatal conductance is essential for higher yield potential of C-3 crops. Crit. Rev. Plant Sci. 2015, 34, 429-453. [CrossRef]

130. Fischer, R.A.; Rebetzke, G.J. Indirect selection for potential yield in early-generation, spaced plantings of wheat and other small-grain cereals: A review. Crop Pasture Sci. 2018, 69, 439-459. [CrossRef]

131. Sepulcre-Cantó, G.; Zarco-Tejada, P.J.J.; Jiménez-Muñoz, J.C.C.; Sobrino, J.A.A.; de Miguel, E.; Villalobos, F.J.J. Detection of water stress in an olive orchard with thermal remote sensing imagery. Agric. For. Meteorol. 2006, 136, 31-44. [CrossRef]

132. Bellvert, J.; Zarco-Tejada, P.J.; Girona, J.; Fereres, E. Mapping crop water stress index in a 'Pinot-noir' vineyard: Comparing ground measurements with thermal remote sensing imagery from an unmanned aerial vehicle. Precis. Agric. 2014, 15, 361-376. [CrossRef]

133. Berni, J.A.J.; Zarco-Tejada, P.J.; Sepulcre-Cantó, G.; Fereres, E.; Villalobos, F. Mapping canopy conductance and CWSI in olive orchards using high resolution thermal remote sensing imagery. Remote Sens. Environ. 2009, 113, 2380-2388. [CrossRef]

134. Alchanatis, V.; Cohen, Y.; Cohen, S.; Moller, M.; Sprinstin, M.; Meron, M.; Tsipris, J.; Saranga, Y.; Sela, E. Evaluation of different approaches for estimating and mapping crop water status in cotton with thermal imaging. Precis. Agric. 2010, 11, 27-41. [CrossRef]

135. Gonzalez-Dugo, V.; Zarco-Tejada, P.; Berni, J.A.J.A.J.; Suarez, L.; Goldhamer, D.; Fereres, E.; Suárez, L.; Goldhamer, D.; Fereres, E. Almond tree canopy temperature reveals intra-crown variability that is water stress-dependent. Agric. For. Meteorol. 2012, 154, 156-165. [CrossRef]

136. Deery, D.M.; Rebetzke, G.J.; Jimenez-Berni, J.A.; James, R.A.; Condon, A.G.; Bovill, W.D.; Hutchinson, P.; Scarrow, J.; Davy, R.; Furbank, R.T. Methodology for high-throughput field phenotyping of canopy temperature using airborne thermography. Front. Plant Sci. 2016, 7, 1808. [CrossRef]

137. Perich, G.; Hund, A.; Anderegg, J.; Roth, L.; Boer, M.P.; Walter, A.; Liebisch, F.; Aasen, H. Assessment of multi-image unmanned aerial vehicle based high-throughput field phenotyping of canopy temperature. Front. Plant Sci. 2020, 11, 150. [CrossRef]

138. Gonzalez-Dugo, V.; Hernandez, P.; Solis, I.; Zarco-Tejada, P.J. Using high-resolution hyperspectral and thermal airborne imagery to assess physiological condition in the context of wheat phenotyping. Remote Sens. 2015, 7, 13586-13605. [CrossRef]

139. Camino, C.; Gonzalez-Dugo, V.; Hernandez, P.; Zarco-Tejada, P.J. Radiative transfer Vcmax estimation from hyperspectral imagery and SIF retrievals to assess photosynthetic performance in rainfed and irrigated plant phenotyping trials. Remote Sens. Environ. 2019, 231, 111186. [CrossRef] 
140. Maes, W.H.; Steppe, K. Estimating evapotranspiration and drought stress with ground-based thermal remote sensing in agriculture: A review. J. Exp. Bot. 2012, 63, 4671-4712. [CrossRef]

141. Nieto, H.H.; Kustas, W.P.; Torres-Rúa, A.; Alfieri, J.G.; Gao, F.; Anderson, M.C.; White, W.A.; Song, L.; del Mar Alsina, M.; Prueger, J.H.; et al. Evaluation of TSEB turbulent fluxes using different methods for the retrieval of soil and canopy component temperatures from UAV thermal and multispectral imagery. Irrig. Sci. 2019, 37, 389-406. [CrossRef]

142. Bendig, J.; Yu, K.; Aasen, H.; Bolten, A.; Bennertz, S.; Broscheit, J.; Gnyp, M.L.; Bareth, G. Combining UAV-based plant height from crop surface models, visible, and near infrared vegetation indices for biomass monitoring in barley. Int. J. Appl. Earth Obs. Geoinf. 2015, 39, 79-87. [CrossRef]

143. Holman, F.H.; Riche, A.B.; Michalski, A.; Castle, M.; Wooster, M.J.; Hawkesford, M.J. High throughput field phenotyping of wheat plant height and growth rate in field plot trials using UAV based remote sensing. Remote Sens. 2016, 8, 1031. [CrossRef]

144. Madec, S.; Baret, F.; de Solan, B.; Thomas, S.; Dutartre, D.; Jezequel, S.; Hemmerlé, M.; Colombeau, G.; Comar, A. High-throughput phenotyping of plant height: Comparing unmanned aerial vehicles and ground LiDAR estimates. Front. Plant Sci. 2017, 8, 2002. [CrossRef]

145. Shi, Y.; Thomasson, J.A.; Murray, S.C.; Pugh, N.A.; Rooney, W.L.; Shafian, S.; Rajan, N.; Rouze, G.; Morgan, C.L.S.; Neely, H.L.; et al. Unmanned aerial vehicles for high-throughput phenotyping and agronomic research. PLoS ONE 2016, 11, e0159781. [CrossRef]

146. Levy, C.R.; Burakowski, E.; Richardson, A.D. Novel measurements of fine-scale albedo: Using a commercial quadcopter to measure radiation fluxes. Remote Sens. 2018, 10, 1303. [CrossRef]

147. Simko, I.; Jimenez-Berni, J.A.; Sirault, X.R.R. Phenomic approaches and tools for phytopathologists. Phytopathology 2017, 107, 6-17. [CrossRef]

148. Vergara-Diaz, O.; Kefauver, S.C.; Elazab, A.; Nieto-Taladriz, M.T.; Araus, J.L. Grain yield losses in yellow-rusted durum wheat estimated using digital and conventional parameters under field conditions. Crop J. 2015, 3, 200-210. [CrossRef]

149. Anderegg, J.; Hund, A.; Karisto, P.; Mikaberidze, A. In-field detection and quantification of Septoria tritici Blotch in diverse wheat germplasm using spectral-temporal features. Front. Plant Sci. 2019, 10, 1355. [CrossRef] [PubMed]

150. Yu, K.; Anderegg, J.; Mikaberidze, A.; Karisto, P.; Mascher, F.; McDonald, B.A.; Walter, A.; Hund, A. Hyperspectral canopy sensing of wheat Septoria tritici blotch disease. Front. Plant Sci. 2018, 9, 1195. [CrossRef] [PubMed]

151. Zheng, Q.; Huang, W.; Cui, X.; Dong, Y.; Shi, Y.; Ma, H.; Liu, L. Identification of wheat yellow rust using optimal three-band spectral indices in different growth stages. Sensors 2018, 19, 35. [CrossRef] [PubMed]

152. Ashourloo, D.; Mobasheri, M.; Huete, A. Evaluating the effect of different wheat rust disease symptoms on vegetation indices using hyperspectral measurements. Remote Sens. 2014, 6, 5107-5123. [CrossRef]

153. Ashourloo, D.; Aghighi, H.; Matkan, A.A.; Mobasheri, M.R.; Rad, A.M. An investigation into machine learning regression techniques for the leaf rust disease detection using hyperspectral measurement. IEEE J. Sel. Top. Appl. Earth Obs. Remote Sens. 2016, 9, 4344-4351. [CrossRef]

154. Bebronne, R.; Carlier, A.; Meurs, R.; Leemans, V.; Vermeulen, P.; Dumont, B.; Mercatoris, B. In-field proximal sensing of septoria tritici blotch, stripe rust and brown rust in winter wheat by means of reflectance and textural features from multispectral imagery. Biosyst. Eng. 2020, 197, 257-269. [CrossRef]

155. Bohnenkamp, D.; Behmann, J.; Mahlein, A.-K. In-field detection of yellow rust in wheat on the ground canopy and UAV scale Remote Sens. 2019, 11, 2495. [CrossRef]

156. Su, J.; Liu, C.; Coombes, M.; Hu, X.; Wang, C.; Xu, X.; Li, Q.; Guo, L.; Chen, W.-H. Wheat yellow rust monitoring by learning from multispectral UAV aerial imagery. Comput. Electron. Agric. 2018, 155, 157-166. [CrossRef]

157. Odilbekov, F.; Armoniené, R.; Henriksson, T.; Chawade, A. Proximal phenotyping and machine learning methods to identify Septoria tritici blotch disease symptoms in wheat. Front. Plant Sci. 2018, 9, 685. [CrossRef] [PubMed]

158. Gallego-Sánchez, L.M.; Canales, F.J.; Montilla-Bascón, G.; Prats, E. RUST: A robust, user-friendly script tool for rapid measurement of rust disease on cereal leaves. Plants 2020, 9, 1182. [CrossRef]

159. Czedik-Eysenberg, A.; Seitner, S.; Güldener, U.; Koemeda, S.; Jez, J.; Colombini, M.; Djamei, A. The 'PhenoBox', a flexible, automated, open-source plant phenotyping solution. New Phytol. 2018, 219, 808-823. [CrossRef]

160. Bingham, I.J.; Walters, D.R.; Foulkes, M.J.; Paveley, N.D. Crop traits and the tolerance of wheat and barley to foliar disease. Ann. Appl. Biol. 2009, 154, 159-173. [CrossRef]

161. Carretero, R.; Serrago, R.A.; Bancal, M.O.; Perelló, A.E.; Miralles, D.J. Absorbed radiation and radiation use efficiency as affected by foliar diseases in relation to their vertical position into the canopy in wheat. Field Crop. Res. 2010, 116, 184-195. [CrossRef]

162. Ney, B.; Bancal, M.O.; Bancal, P.; Bingham, I.J.; Foulkes, J.; Gouache, D.; Paveley, N.; Smith, J. Crop architecture and crop tolerance to fungal diseases and insect herbivory. Mechanisms to limit crop losses. Eur. J. Plant Pathol. 2013, 135, 561-580. [CrossRef]

163. Costes, E.; Lauri, P.E.; Simon, S.; Andrieu, B. Plant architecture, its diversity and manipulation in agronomic conditions, in relation with pest and pathogen attacks. Eur. J. Plant Pathol. 2013, 135, 455-470. [CrossRef]

164. van den Berg, F.; Paveley, N.D.; Bingham, I.J.; van den Bosch, F. Physiological traits determining yield tolerance of wheat to foliar diseases. Phytopathology 2017, 107, 1468-1478. [CrossRef]

165. Deery, D.; Jimenez-Berni, J.; Jones, H.; Sirault, X.; Furbank, R. Proximal Remote Sensing Buggies and Potential Applications for Field-Based Phenotyping. Agronomy 2014, 5, 349-379. [CrossRef]

166. Rebetzke, G.J.; Jimenez-Berni, J.A.; Bovill, W.D.; Deery, D.M.; James, R.A. High-throughput phenotyping technologies allow accurate selection of stay-green. J. Exp. Bot. 2016, 67, 4919-4924. [CrossRef] [PubMed] 